\title{
OBTAINING NIOBIUM OXIDES IN ACETIC ACID WITH ADDITION OF HF
}

\author{
Patrícia Marcolin ' \\ Marielen Longhi ${ }^{2}$ \\ Letícia Caio ${ }^{3}$ \\ Lucas Pandolphi Zini ${ }^{3}$ \\ Lilian Vanessa Rossa Beltrami ${ }^{4}$ \\ Jéssica Cristina Silva ${ }^{5}$ \\ Fernando Dal Pont Morisso ${ }^{5}$ \\ Sandra Raquel Kunst ${ }^{\prime}$ \\ Cláudia Trindade Oliveira ${ }^{5}$
}

\begin{abstract}
During anodizing, the chemical attack of hydrofluoric acid (HF) electrolytes on niobium can promote the formation of oxides with porous structures. However, this chemical attack can also cause an intense dissolution of the oxide during its formation. This effect can be minimized by varying the HF concentration of the anodizing electrolyte, thereby controlling the growth of the porous oxide. Studies have alternative electrolytes that do not use HF to obtain porous oxides. Thus, organic electrolytes, such as acetic acid, may be a viable alternative. In this context, the objective of this study is to obtain and evaluate the anodization of niobium in acetic acid at different current densities $\left(10,20\right.$ and $\left.50 \mathrm{~mA} / \mathrm{cm}^{2}\right)$ and to study the influence of the addition of HF to the electrolyte. The results showed that the anodized anodic in acetic acid, under conditions of $100 \mathrm{~V}$ and $10 \mathrm{~mA} / \mathrm{cm}^{2}$, presented porous oxide with less defects. Therefore, this result indicates that it is possible to produce porous niobium oxides by anodizing in HF-free electrolyte.
\end{abstract}

Keywords: Niobium; Anodizing; Acetic acid.

\section{OBTENÇÃO DE ÓXIDOS DE NIÓBIO EM ÁCIDO ACÉTICO COM ADIÇÃO DE HF}

\section{Resumo}

Durante a anodização, o ataque químico de eletrólitos de ácido fluorídrico (HF) sobre o nióbio pode promover a formação de óxidos com estruturas porosas. Contudo, este ataque químico pode causar uma intensa dissolução do óxido durante sua formação. Esse efeito pode ser minimizado variando-se a concentração de HF do eletrólito de anodização, controlando assim o crescimento do óxido poroso. Estudos têm buscado por eletrólitos alternativos que não utilizam $\mathrm{HF}$ na obtenção de óxidos porosos. Logo, eletrólitos orgânicos, como o ácido acético, podem ser uma alternativa viável. Neste contexto, o objetivo deste estudo é obter e avaliar a anodização de nióbio em ácido acético em diferentes densidades de correntes ( 10,20 e $50 \mathrm{~mA} / \mathrm{cm}^{2}$ ) e estudar a influencia da adição de $\mathrm{HF}$ ao eletrólito. Os resultados mostraram que a amostra de nióbio anodizada em ácido acético, nas condições de $100 \mathrm{~V}$ e $10 \mathrm{~mA} / \mathrm{cm}^{2}$, apresentou óxido proroso com menor quantidade de defeitos. Portanto, este resultado indica que é possível a formação de óxidos de nióbio porosos por anodização em eletrólito livre de HF.

Palavras-chave: Nióbio; Anodização; Ácido acético.

'Programa de Pós-graduação em Engenharia de Processos e Tecnologias - PGEPROTEC, Universidade de Caxias do Sul - UCS, Caxias do Sul, RS, Brazil.E-mail: pmarcolin@ucs.br

${ }^{2}$ Programa de Pós-graduação em Engenharia de Minas, Metalúrgica e de Materiais - PPGE3M, Universidade Federal do Rio Grande do Sul - UFRGS, Porto Alegre, RS, Brazil.

${ }^{3}$ Laboratório de Corrosão - LCOR, Universidade de Caxias do Sul - UCS, Caxias do Sul, RS, Brazil.

${ }^{4}$ Laboratório de Pesquisa em Corrosão - LAPEC, Universidade Federal do Rio Grande do Sul - UFRGS, Porto Alegre, RS, Brazil.

${ }^{5}$ Instituto de Ciências Exatas e Tecnológicas - ICET, Universidade Feevale, Novo Hamburgo, RS, Brazil.

2176-1523 (C) 2016 Associação Brasileira de Metalurgia, Materiais e Mineração. Publicado pela ABM. Este é um artigo de acesso aberto distribuído sob os termos da licença Creative Commons CC BY-NC-ND (Attribution-NonCommercial-NoDerivs) - https:// creativecommons.org/licenses/by-nc-nd/4.0\%. 


\section{INTRODUCTION}

Metals that form an oxide layer through anodizing are classified as metal valve. Anodizing is an ideal process for creating fine and homogeneous oxide layers with good dielectric and semiconductor properties. It oxidizes in temperatures above $200^{\circ} \mathrm{C}$. Its most common oxidation states are $2^{+}, 4^{+}$and $5^{+}$. Niobium oxide (II) presents superconductivity in temperatures near absolute zero and is used in circuits as resistor. The oxide with oxidation number $4^{+}$acts as an excellent semiconductor. However, $\mathrm{Nb}_{2} \mathrm{O}_{5}$ is the most stable compound and demonstrates good corrosion resistance in acid and basic environments, high refractive index and low absorption in UV-visible region [1,2].

Anodization allows the formation of two types of oxides: barrier and porous. The barrier oxides are obtained in electrolytes that do not attack it $[1,3]$. While porous oxides are formed in electrolytes that chemically attack the oxide. In this process, first the barrier oxide is formed, followed by dissolution of the same, which gives rise to the pores. This dissolution occurs by migration of the acid anion into the oxide film, forming a complex with the metal, which is soluble in water and responsible for pore formation [4].

Due to its biocompatibility and osteoconductivity, this oxide class has potential application in the area of nanobiotechnology, due to the control of pore formation, such as size and uniformity, which favor cell growth $[5,6]$.

Niobium can be applied in production of nanotubes, nanowires and membranes. In form of oxide, niobium can be used in gas sensors, solar cells, implants, electronic and magnetic devices and biotechnology [7].

These oxides are obtained through an anodizing process and may form barrier and porous oxides. Barrier oxides are obtained in electrolytes that does not attack the oxide. The electrolytes used for anodizing are generally acid, because they present better results $[1,3]$.

The excellent corrosion resistance of niobium in many environments is attributed to the presence of a superficial film of stable oxide $\left(\mathrm{Nb}_{2} \mathrm{O}_{5}\right)$, protector and strongly adherent. In front of their applicability and high corrosion resistance, despite its relatively high cost, niobium is a material that has stood out in the scientific and technologic landscape [8].

The choice of the appropriated material for equipment, projects and controlled operations, constitute the largest controlling weapons of corrosive process. Niobium, being a very corrosion resistant in various environments, becomes a promising material for many segments of industries. Some studies related to pure niobium behavior and its alloys in various environments were published. Most of them show the good corrosion resistance, especially in aqueous environments [I,3].

Currently, the formation of porous structures in niobium occurs very efficiently in electrolytes containing hydrofluoric acid (HF), that may cause an intense dissolution. Meanwhile, in a controlled manner, through this dissolution oxide can be obtained [7]. Considering the harmfulness of HF, studies are being performed with organic electrolytes, such as acetic acid, to form porous oxide with orderly growth.
In this context, in order to obtain continuous oxides and with uniform pores, the objective of this study is to promote the anodization of niobium in the acetic acid electrolyte and to evaluate the influence of different current densities and the concentration of HF in the electrolyte.

\section{EXPERIMENTAL}

Pure niobium $(99.5 \%)$ was provided in form of plates by Companhia Brasileira de Metalurgia e Mineração (CBMM). Samples were analyzed for anodizing curves. Morphology and deposited film thickness were evaluated by scanning electron microscopy (SEM).

Samples were cut into the dimensions of $2.0 \times 1.0 \mathrm{~cm}$ and, posteriorly, drilled on one end for securing the electric contact. Electrical insulation was made, leaving an exposed area of $\mathrm{Icm}^{2}$ on each side of the sample.

Samples was pickling in solution of hydrofluoric acid (HF) $40 \%$ and nitric acid $\left(\mathrm{HNO}_{3}\right) 60 \%$ during 5 minutes, with stirring. Afterwards, they were rinsed with deionized water and dried with cold air. On the anodizing process was used the equipment brand Minipa model MPL-3303 with a voltage source $300 \mathrm{~V}$ and $0.5 \mathrm{~A}$, which was connected to a computer for data acquisition. Potential was chosen in order to force occurring of breakdown, to characterize the samples to the edge of barrier oxide formation. Variations of current densities used were 10,20 and $50 \mathrm{~mA} / \mathrm{cm}^{2}$. Table I shows the nomenclature used for the samples analyzed in this research and process parameters are described in Tables 2, 3 and 4.

For scanning electron microscopy, it was used an equipment Jeol JSM-65 I OLV Scanning Electron Microscope. Samples were analyzed in top view in order to obtain information related to the morphology of the oxide formed on the substrate surface. Samples were also evaluated through cross section, with metallization with golden film.

Oxide densities of anodized samples were calculated based on niobium oxide thicknesses and on anodizing curves, according to Equation I, through Faraday Law. Calculated values are listed on Table 5.

$$
\rho=\frac{i t M}{z F D}
$$

Where:

$$
\begin{aligned}
& \rho=\text { density }\left(\mathrm{g} / \mathrm{cm}^{3}\right) ; \\
& \mathrm{i}=\text { current density }\left(\mathrm{A} / \mathrm{cm}^{2}\right) ; \\
& \mathrm{t}=\text { time that i remains constant }(\mathrm{s}) ; \\
& M=N b \text { molar mass }(265,8 \mathrm{I} \mathrm{g} / \mathrm{mol}) ; \\
& \mathrm{z}=10 \text {, product of niobium and oxygen oxidation states; } \\
& \mathrm{F}=\text { Faraday constant }\left(9,64 \times 10^{-4} \mathrm{C} / \mathrm{mol}\right) ; \\
& D=\text { thickness }(\mathrm{cm}) . \\
& \quad \text { Oxide production rate was calculated through } \\
& \text { Equation } 2 . \text { The values are listed on Table } 4 .
\end{aligned}
$$

$$
\text { Oxide production rate }=\frac{\text { Thickness }}{\text { Timeto reach } 100 \mathrm{~V}}
$$


Table I. Samples and anodizing conditions

\begin{tabular}{|c|c|c|c|}
\hline $\begin{array}{l}\frac{0}{0} \\
\text { ज़๊ } \\
\text { ज̆ }\end{array}$ & Electrolyte & $\begin{array}{c}\text { Current } \\
\text { density } \\
\left(\mathrm{mA} / \mathrm{cm}^{2}\right)\end{array}$ & $\begin{array}{c}\text { Applied } \\
\text { Potential } \\
\text { (V) }\end{array}$ \\
\hline $\mathrm{Nb} 0$ & -- & 0 & 0 \\
\hline $\mathrm{Nb} I$ & Acetic acid I mol/L & 10 & 300 \\
\hline $\mathrm{Nb} 2$ & Acetic acid I mol/L & 20 & 300 \\
\hline Nb 3 & Acetic acid I mol/L & 50 & 300 \\
\hline $\mathrm{Nb} 4$ & Acetic acid I mol/L & 10 & 100 \\
\hline $\mathrm{Nb} 5$ & Acetic acid I mol/L + HF $0.01 \mathrm{~mol} / \mathrm{L}$ & 10 & 100 \\
\hline $\mathrm{Nb} 6$ & Acetic acid I mol$/ \mathrm{L}+\mathrm{HF} 0.1 \mathrm{~mol} / \mathrm{L}$ & 10 & 100 \\
\hline $\mathrm{Nb} 7$ & Acetic acid I mol/L + HF I mol/L & 10 & 100 \\
\hline
\end{tabular}

Table 2. Potential variation in function of time during anodizing (acetic acid I mol/L, $300 \mathrm{~V}$ )

\begin{tabular}{ccc}
\hline Sample & $\partial \mathbf{V} / \partial \mathbf{t}(\mathbf{V} / \mathbf{s})$ & $\mathbf{V b}(\mathbf{V})$ \\
\hline $\mathrm{Nb} I\left(10 \mathrm{~mA} / \mathrm{cm}^{2}\right)$ & 2.22 & 275 \\
$\mathrm{Nb} 2\left(20 \mathrm{~mA} / \mathrm{cm}^{2}\right)$ & 3.45 & 275 \\
$\mathrm{Nb} \mathrm{3}\left(50 \mathrm{~mA} / \mathrm{cm}^{2}\right)$ & 9.54 & 300 \\
\hline
\end{tabular}

Table 3. Oxide growth rate in niobium samples at $10 \mathrm{~mA} / \mathrm{cm}^{2}$ and $100 \mathrm{~V}$

\begin{tabular}{cc}
\hline Sample & $\partial \mathbf{V} / \partial \mathbf{t}(\mathbf{V} / \mathbf{s})$ \\
\hline $\mathrm{Nb} 4$ & 1.84 \\
$\mathrm{Nb} 5$ & 3.45 \\
$\mathrm{Nb} 6$ & 2.10 \\
$\mathrm{Nb7}$ & 1.27 \\
\hline
\end{tabular}

Table 4. Production and dissolution rate, $\partial \mathrm{V} / \partial \mathrm{t}$, time to reach $100 \mathrm{~V}$ and thickness, values obtained from cross section of the samples

\begin{tabular}{|c|c|c|c|c|}
\hline$\frac{0}{\frac{0}{0}}$ & 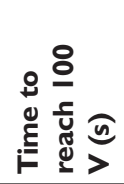 & 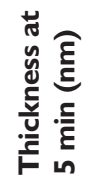 & 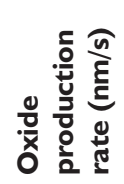 & 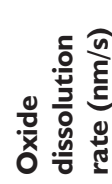 \\
\hline $\mathrm{Nb} 4$ & 57 & 560 & 10.98 & - \\
\hline Nb5 & 22 & 301 & 13.68 & - \\
\hline Nb6 & 50 & 301 & 6.02 & 7.66 \\
\hline $\mathrm{Nb7}$ & 85 & 481 & 5.65 & 8.03 \\
\hline
\end{tabular}

Table 5. Densities for oxides formed at $10 \mathrm{~mA} / \mathrm{cm}^{2}$, acetic acid I mol/L, with and without $\mathrm{HF}$

\begin{tabular}{|c|c|c|c|}
\hline$\frac{y}{\frac{y}{2}}$ & Thickness (cm) & $\begin{array}{l}\text { Time to reach } \\
\text { Vb and stabilize } \\
\text { potential (s) }\end{array}$ & Density $\left(\mathrm{g} / \mathrm{cm}^{3}\right)$ \\
\hline $\mathrm{Nb} 4$ & $0.560 \times 10^{-4}$ & 57 & 2.8066 \\
\hline $\mathrm{Nb5}$ & $0.301 \times 10^{-4}$ & 22 & 2.0153 \\
\hline $\mathrm{Nb6}$ & $0.301 \times 10^{-4}$ & 50 & 4.5803 \\
\hline $\mathrm{Nb7}$ & $0.481 \times 10^{-4}$ & 85 & 4.8726 \\
\hline
\end{tabular}

\section{RESULTS AND DISCUSSION}

Figure I illustrates the scheme of different regions present on the potential versus time transients during niobium anodizing. And the Figure 2 shows potential and current transients measured during anodizing in acetic acid $1 \mathrm{~mol} / \mathrm{L}, 300 \mathrm{~V}$ and $\mathrm{I} 0,20$ and $50 \mathrm{~mA} / \mathrm{cm}^{2}$.

Region I (Figure I and 2), shows a linear increasing of potential in function of time, generating a constant $(\partial \mathrm{V} / \partial \mathrm{t})$, designated anodizing rate. In this region, it is observed a characteristic behavior of barrier film formation wherein all the current density is used for film formation. $\partial \mathrm{V} / \partial \mathrm{t}$ variation remains constant until reach the dielectric breakdown potential $(\mathrm{Vb})$, wherein occurs a decrease of $\partial \mathrm{V} / \partial \mathrm{t}$ value, showing the beginning of region 2 (Figure I and 2). As the Figure 2, the largest potential value is for the anodized sample in $50 \mathrm{~mA} / \mathrm{cm}^{2}$. This variation in $\partial \mathrm{V} / \partial \mathrm{t}$, from region I to region 2 , has been already observed in other metals when anodized, characteristic of the dielectric breakdown beginning $[1,9]$. Region 2 is characterized by presenting a potential almost constant [9].

$\partial \mathrm{V} / \partial \mathrm{t}$ values measured for anodized $\mathrm{Nb}$ in the different current densities are shown on Table 2.

According with Table 2, despite the anodizing have been made at $300 \mathrm{~V}$, only the sample at $50 \mathrm{~mA} / \mathrm{cm}^{2}$ demonstrated breakdown potential of $300 \mathrm{~V}$, being accompanied by oscillations in the current density, characteristics of breakdown. The other samples showed breakdown potential around $275 \mathrm{~V}$, not being possible to identify oscillations in the current density. This indicates that increasing of current density promotes formation of an oxide with a higher growing rate and, consequently, higher dielectric breakdown potential.

Niobium films, grown with higher $\partial \mathrm{V} / \partial \mathrm{t}$, presented larger probability of defects formation than the formed with lower $\partial \mathrm{V} / \partial \mathrm{t}$. This could explain the higher $\mathrm{Vb}$ obtained in this sample of $50 \mathrm{~mA} / \mathrm{cm}^{2}$ and the observed oscillations [10].

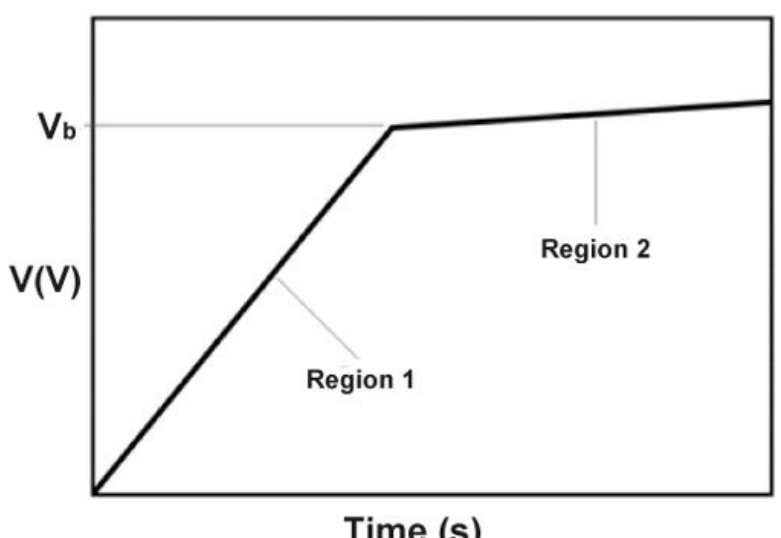

Figure I. Illustrative scheme of different regions present in potential transients versus time graphs of Figure I during niobium anodizing. 
Towards the context of this study, it was decided to anodize niobium at $10 \mathrm{~mA} / \mathrm{cm}^{2}$, to ensure the oxide formation with lower quantity of defects and at a potential lesser than $300 \mathrm{~V}$, avoiding occurrence of sparking. Is was also noticed the formation of porous oxides by adding HF to the electrolyte.

Figure 3 illustrates potential and current transients of niobium anodized with acetic acid $\mathrm{I} \mathrm{mol} / \mathrm{L}$, at $10 \mathrm{~mA} / \mathrm{cm}^{2}$ and $100 \mathrm{~V}$, without adding $\mathrm{HF}$ and with additions of $0.0 \mathrm{I}, 0 . \mathrm{I}$ and I mol/L of HF. All the samples demonstrated similar behaviors, beginning with a linear increasing of potential, wherein current density remains constant at $10 \mathrm{~mA} / \mathrm{cm}^{2}$. After reaching potential of $100 \mathrm{~V}$, the samples preserve the potential constant and there is an abrupt decrease of the current density, indicating the end of film formation. In this case, it cannot be said that film formation is completely barrier, once the addition of HF induces the formation of a porous film.

Table 3 shows the growth rate of oxides formed with and without addition of HF. According with Table 3, the increase of $\mathrm{HF}$ concentration decreases the growth rate of oxide. It was observed a similar behavior with addition of $\mathrm{HF}$ in oxalic acid in niobium anodizing, wherein $\mathrm{HF}$ induces the dissolution of the oxide. The dissolution process occurs concurrently with the barrier oxide formation, being directly proportional to the increase of HF concentration. Figure 4 exemplifies the occurrence of this factor.

In Figure 4, the steps of formation refer to the niobium oxide formation without addition of HF, where it is noticed the continuous growth of the niobium oxide. The sequence illustrated in the entire figure refers to the oxide film formation and dissolution, which elucidates the observed low anodizing rate [4].

Figure 5a-c show the micrographs in top view and cross section of the anodized samples in acetic acid I mol/L, at $300 \mathrm{~V}$ and 10,20 and $50 \mathrm{~mA} / \mathrm{cm}^{2}$. It is seen, in these samples, an irregular surface with imperfections, which become more evident with increasing of current density. The sample obtained at $10 \mathrm{~mA} / \mathrm{cm}^{2}$ demonstrates,
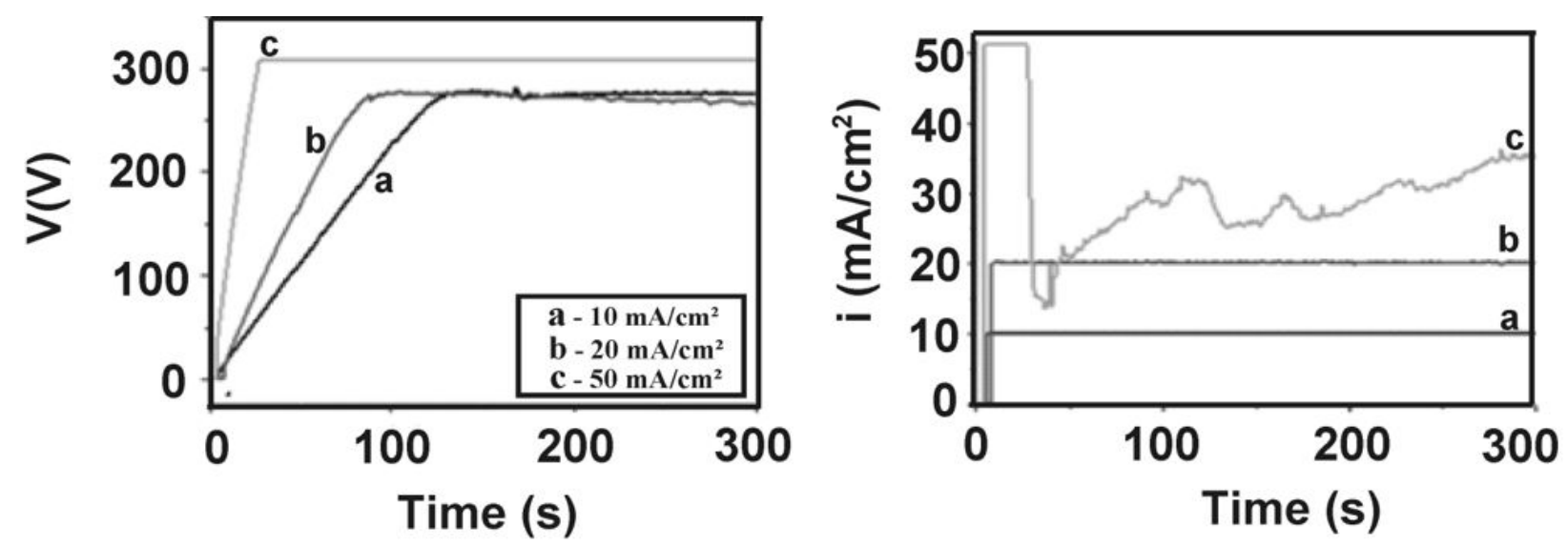

Figure 2. Potential and current transients in function of time, measured during niobium anodizing in 10,20 and $50 \mathrm{~mA} / \mathrm{cm}^{2}$, at $300 \mathrm{~V}$ in acetic acid I mol/L.
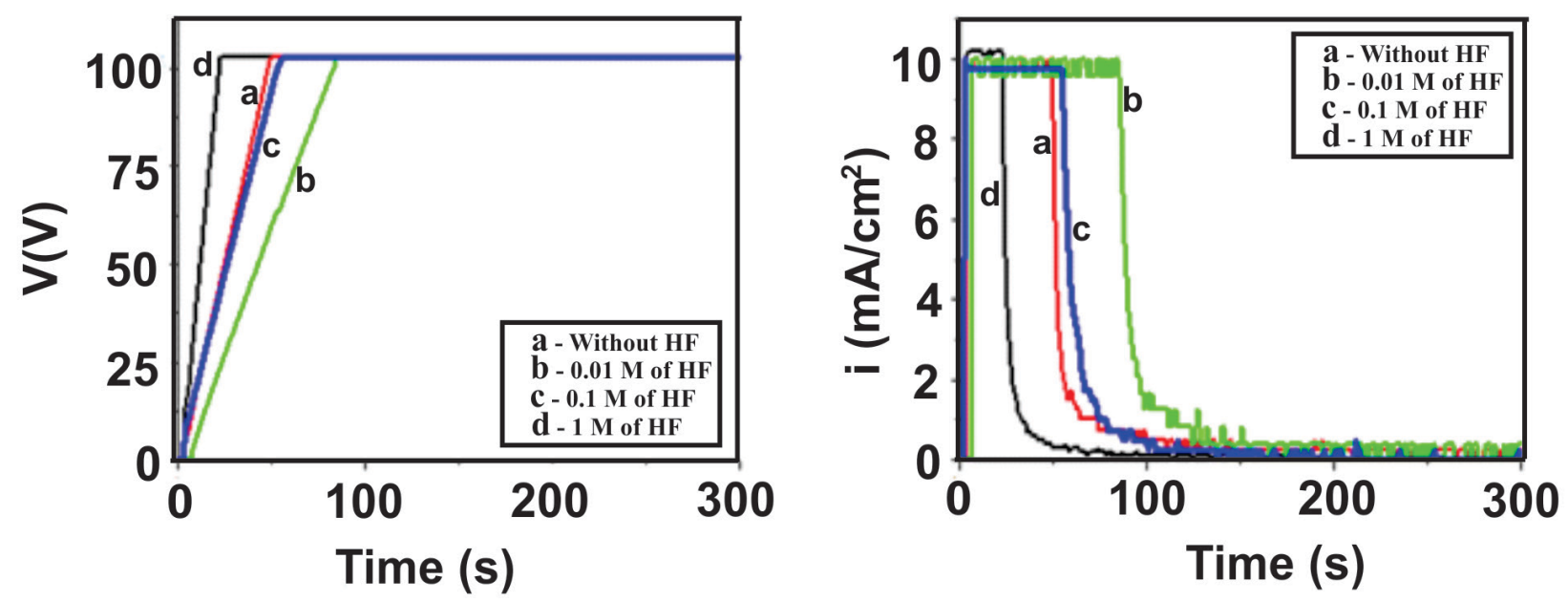

Figure 3. Potential and current transients versus time for anodized niobium at $100 \mathrm{~V}$ in acetic acid $\mathrm{I}$ mol/L with and without adding of $\mathrm{HF}$. 


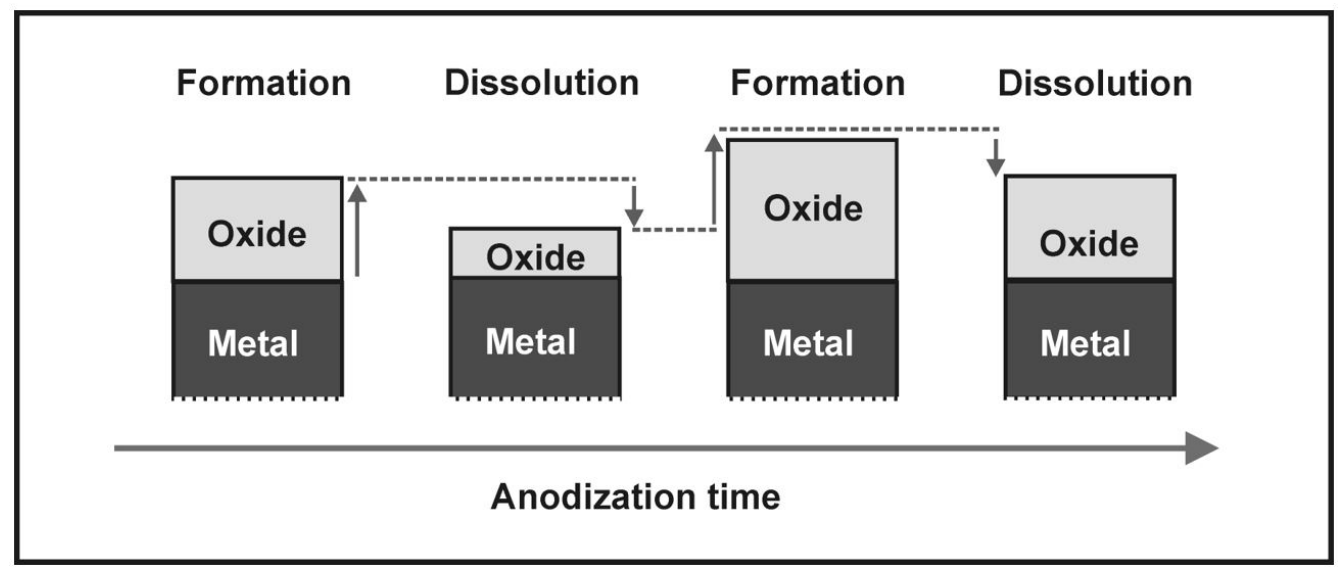

Figure 4. Dissolution model of niobium oxide formed in acetic acid with addition of HF.
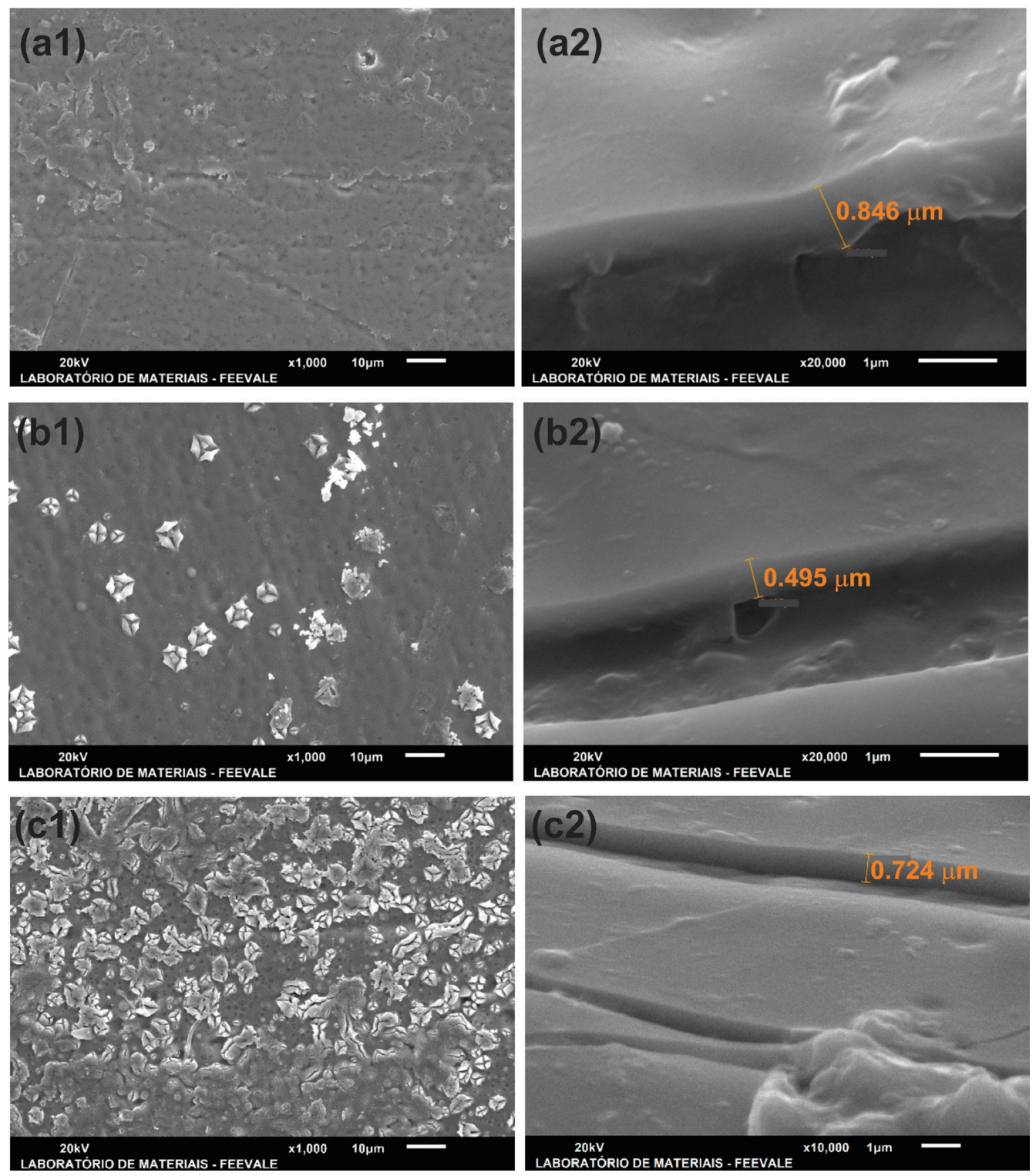

Figure 5. (a) Micrograph of Nb2 sample: (al) top view and (a2) cross section; (b) Micrograph of Nb2 sample: (bl) top view and (b2) cross section; (c) Micrograph of $\mathrm{Nb3}$ sample: (cl) top view and (c2) cross section. 
besides imperfections, the formation of pores, like pits on the niobium surface.

The occurrence of breakdown can also manifest in form of random pits on the surface of anodized sample. With increasing of current density and, consequently, with the increase of electrons amount for oxide formation, located points of occurrence of breakdown are noticed clearly.
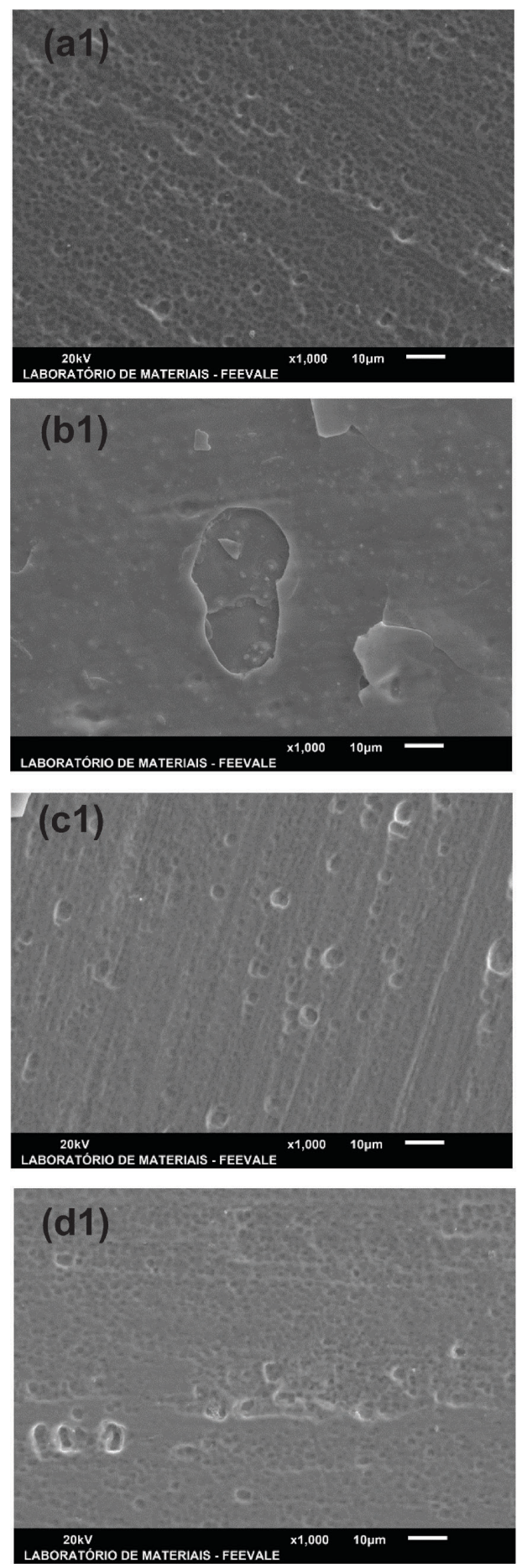

Figure 6. (a) Micrograph of Nb4 sample: (al) top view and (a2) cross section; (b) Micrograph of Nb5 sample, obtained in acetic acid I mol/L + HF 0.0I mol/L at $100 \mathrm{~V}$ for 5 minutes: (bl) top view and (b2) cross section; (c) Micrograph of Nb6 sample: (cl) top view and (c2) cross section; (d) Micrograph of Nb7 sample: (dI) top view and (d2) cross section. 
The sample in presence of acetic acid showed pores on substrate surface, however, the oxides formation occurs generally in environments containing strong electrolytes able to attack chemically the substrate. Specifically, in case of niobium, porous oxide formation occurs in electrolytes that contain $\mathrm{HF}$ or at $\mathrm{pH}=\mathrm{I} 4$ [12]. The formation in presence of an organic electrolyte, acetic acid in this case, occurs probably because there is a small amount of oxygen compared to aqueous solutions, thus favoring the oxide chemical dissolution in function of oxide formation [13].

In acetic acid, the maximum thickness of an intact anodic film is less than $25 \mathrm{~nm}$, and thicker films, obtained at higher potentials, contain imperfections in their pit appearance morphology [14]. It has been reported that anodizing in organic electrolyte produces very smooth curves of anodizing, without any fluctuations in the current, which was attributed to the low concentration and diffusivity of ions in the organic electrolyte [15]. An organic electrolyte has a small amount of oxygen compared to an aqueous solution and therefore the chemical dissolution of the oxide in an organic electrolyte depends on the water content [16]. Consequently, for the formation of porous oxides in the form of nanotubes, a thicker layer of nanotubes will form over a long time in an organic electrolyte, and the viscosity of the electrolyte, whether under agitation or not and the content of $\mathrm{H}_{2} \mathrm{O}$, may influence the Formation of the nanotube [17].

With addition of $0.01 \mathrm{~mol} / \mathrm{L}$ of $\mathrm{HF}$, there is pores formation with less intensity. Therefore, the addition of $\mathrm{HF}$ induces the pores formation and acetic acid inhibits the dissolution process. The gradual increase of pores on the samples is proportional to the increase of $\mathrm{HF}$ concentration, however the oxides formed in organic electrolytes were irregular.

Through time and thickness values showed on Table 5, the oxide production rate can be calculated by the Equation 2.

To calculate the oxide formation rate, only the thicknesses of oxides formed until $300 \mathrm{~s}$ were used, and the growth of the oxide layer after the time de potential reached $100 \mathrm{~V}$ was not considered significant.

According to Table 4, it is observed that occurs an increase of the oxide production rate with addition of HF $0.01 \mathrm{~mol} / \mathrm{L}$ to the electrolyte of anodizing - acetic acid I mol/L. This corresponds to the obtained results for the anodized sample in acetic acid I mol/L, in which occurs pores formation and consequent oxide dissolution.

Comparing only the anodized samples containing $\mathrm{HF}$, it is noticed that the increase of $\mathrm{HF}$ concentration raises the oxide dissolution rate, favoring the formation of porous oxide. According to Figure 6a2, b2, c2 and d2, oxides cross sections present homogeneous aspect.

To calculate oxide density, only the samples that were not submitted to dieletric breakdown were considered. It was utilized the oxides thickness described on Table 5 to calculate the oxide density. The oxides densities can have varied from $2 \mathrm{~g} / \mathrm{cm}^{3}$ to $4 \mathrm{~g} / \mathrm{cm}^{3}$, with variation in the thickness of formed oxide, as reported in another study in which they performed the anodization of niobium to assess their anodic behavior, and found density values close to $4 \mathrm{~g} / \mathrm{cm}^{3}[12,18]$. It is observed in Table 5 that the oxide formed without presence of $\mathrm{HF}$ presents value inferior to $4 \mathrm{~g} / \mathrm{cm}^{3}$. According to Figure 6 (al) this oxide is of the porous type, which would explain the low density. However, for the oxides obtained with addition of HF, the oxide density increased with the decrease of the HF concentration. In addition, the increase in $\mathrm{HF}$ concentration formed oxides with lower $\partial \mathrm{V} / \partial \mathrm{t}$, consequently with fewer defects [10]. Since HF causes the oxide to dissolve during its formation, this would cause oxide formation to occur in a slower way, therefore with less defects and higher density, which agrees with the model suggested in Figure 4.

\section{CONCLUSIONS}

The formation of niobium oxides in acetic acid only occurs efficiently with the application of lower current density $\left(10 \mathrm{~mA} / \mathrm{cm}^{2}\right)$. During the anodizing process, it was observed that the lower breakdown potential and lower $\partial \mathrm{V} / \partial \mathrm{t}$ resulted in the formation of oxide with less defects.

In addition, the porous niobium oxide formation was obtained by anodization using the I mol/L oxalic acid solution under the conditions of $100 \mathrm{~V}$ and $10 \mathrm{~mA} / \mathrm{cm}^{2}$ as the electrolyte. This result indicates that it is possible to obtain porous niobium foams in free HF electrolytes. However, the addition of HF to the electrolyte favors the formation of porous oxide, where the dissolution process is more intense for higher concentration of $\mathrm{HF}(\mathrm{I} \mathrm{mol} / \mathrm{L})$. Despite this, the oxide obtained in I mol/L HF presented smaller $\partial \mathrm{V} / \partial \mathrm{t}$, leading to the slow formation of the oxide and consequently resulting in an oxide with fewer defects. This would explain the higher density observed for the oxide formed in the higher concentration of HF.

\section{REFERENCES}

I Graça MPF, Saraiva M, Freire FA, Valente MA, Costa LC. Electrical analysis of niobium oxide thin films. Thin Solid Films. 20I5;585:95-99. 
2 Choi J, Lim JH, Lee J, Kim KJ. Porous niobium oxide films prepared by anodization- annealing-anodization. Nanotechnology. 2007; 18:055603.

3 Yao L, Wuhong X, Jiupeng Z, Xiangdong M. Fabrication and characterization of three-dimensionally ordered macroporous niobium oxide. Solid State Sciences. 2009; I I:1625-1630.

4 Kowalski D, Kim D, Schmuki P. TiO2 nanotubes, nanochannels and mesosponge: Self-organized formation and applications. Nano Today. 2013;8(3):235-264.

5 Shi L, Gu Y, Chen L, Yang Z, Ma J, Qian Y. Synthesis and charact of superconducting NbC nanotubes. Carbon. 2005;43:195-213.

6 Tsuneta T, Toshima T, Inagaki K, Hibayama T, Tanda S, Ahlskog M, et al. Formation of metallic $\mathrm{NbSe}_{2}$ nanotubes and nanofibers. Current Applied Physics. 2003;3:473-476.

7 Choi J, Lim JH, Lee SC, Chang JH, Kim KJ, Cho MA. Porous niobium oxide films prepared by anodization in HF/ H3PO4. Electrochimica Acta. 2006;51:5502-5507.

8 Jeong B, Jung E, Kim J. Fabrication on superhydrophobic niobium pentoxide thin films by anodization. Applied Surface Science. 2014;307:28-32.

9 Gomes MAB, Onofre S, Juanto S, Bulhões LOS. Anodization of niobium in sulphuric acid media. Journal of Applied Electrochemistry. 1991;21:1023-1026.

10 El-Mahdy GA. Formation and dissolution behavior of niobium oxide in phosphoric acid solutions. Thin Solid Films. 1997;307:14I-I47.

I I Ikonopisov S. Theory of electrical breakdown during formation of barrier anodic films. Electrochimica Acta. 1977;22:1077-1082.

12 D'Alkaine CV, de Souza LMM, Nart FC. The anodic behaviour of niobium-II. General experimental electrochemical aspects. Corrosion Science. 1993;34:1 I7-I 27.

13 Wan J, Yan X, Ding J, Wang M, Hu K. Self-organized highly ordered TiO2 nanotubes in organic aqueous system. Materials Characterization. 2009;60:1534-1540.

I4 Shi P, Cheng FT, Man HC. Improvement in corrosion resistance of NiTi by anodization in acetic acid. Materials Letters. 2007;61:2385-2388.

15 Yang DJ, Kim HG, Cho SJ, Choi WY. Thickness-conversion ratio from titanium to $\mathrm{TiO}_{2}$ nanotubes fabricated by anodization method. Materials Letters. 2008;62:775-779.

16 Wan J, Yan X, Ding J, Wang M, Hu K. Self-organized highly ordered $\mathrm{TiO}_{2}$ nanotubes in organic aqueous system. Materials Characterization. 2009;60:1534-1540.

17 Narayanan $\mathrm{R}$, Kwon TY, Kim $\mathrm{KH}$. $\mathrm{TiO}_{2}$ nanotubes from stirred glycerol/ $\mathrm{NH}_{4} \mathrm{~F}$ electrolyte: roughness, wetting behavior and adhesion for implant applications. Materials Chemistry and Physics. 2009; I 17:460-464.

$18 \mathrm{Sui} \mathrm{JH}$, Cai W. Formation of $\mathrm{ZrO}_{2}$ coating on the NiTi alloys for improving their surface properties. Nuclear Instruments and Methods in Physics Research. 2006;251:402-406.

Received: 14 Dec. 2016

Accepted: 25 Apr. 2017 